This is the final peer-reviewed accepted manuscript of:

Betalains increase vitexin-2-O-xyloside cytotoxicity in CaCo-2 cancer cells.

Farabegoli F, Scarpa ES, Frati A, Serafini G, Papi A, Spisni E, Antonini E, Benedetti S, Ninfali P.Food Chem. 2017 Mar 1;218:356-364. doi: 10.1016/j.foodchem.2016.09.112. Epub 2016 Sep 17.PMID: 27719921

- The final published version is available online at:

DOI: 10.1016/j.foodchem.2016.09.112

Rights / License:

The terms and conditions for the reuse of this version of the manuscript are specified in the publishing policy. For all terms of use and more information see the publisher's website.

This item was downloaded from IRIS Università di Bologna (https://cris.unibo.it/)

When citing, please refer to the published version. 


\title{
Betalains increase Vitexin-2-O-xyloside cytotoxicity in CaCo-2 cancer cells
}

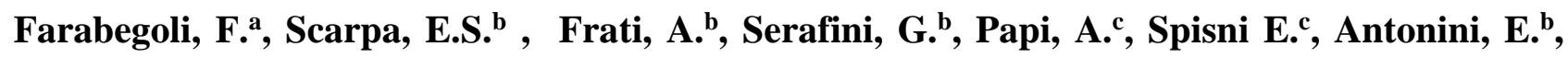
Benedetti, S. ${ }^{\mathbf{b}}$, Ninfali, $\mathbf{P .}^{\mathbf{b}^{*}}$

aDepartment of Pharmacology and Biotechnology, University of Bologna, 40126 Bologna, Italy bDepartment of Biomolecular Sciences, University of Urbino "Carlo Bo", 61029 Urbino, Italy 'Department of Evolutionary Biology, University of Bologna, 40126 Bologna, Italy

*Author to whom correspondence should be addressed; E-Mail: paolino.ninfali@ uniurb.it; Tel.: +39 0722 305288; Fax: +39 0722 305324; Via Saffi 2, 61029 Urbino (PU), Italy.

\begin{abstract}
Phytochemicals with anticancer activity are present in Beta wharis. We purified Vitexin-2-Oxyloside (XVX) from Beta vulgaris var. cicla L. (BVc) seeds, betaxanthins (R1) and betacyanins (R2) fractions from Beta vulgaris var. rubra L. (BVr) roots. Phytochemicals were combined and tested for cytotoxicity in CaCo-2 colon cancer cells. XVX was the most cytotoxic molecule, but the combination of XVX with R1 and R2 significantly protracted its cytotoxicity. Cytotoxicity was mediated by an intrinsic apoptotic pathway, as shown by an increase in Bcl2-like protein 4, cleaved Poly ADP-Ribosyl Polymerase 1 and cleaved Caspase 3 levels with a parallel decrease in antiapoptotic protein B-cell leukemia/lymphoma 2 levels. R1 and R2, used alone or coupled, were alse able to reduced oxidative stress triggered by $\mathrm{H}_{2} \mathrm{O}_{2}$ in $\mathrm{CaCo}-2$. Moreover, Betalains dampened Cyclooxygenase-2 and Interleukin-8 mRNA expression after Lipopolysaccharide induction in CaCo2, showing an anti-inflammatory action. Our results support the use of an efficient nutraceutical a cocktail of R1, R2 and XVX as a chemopreventive tool against colon cancer.
\end{abstract}

Key words: Beta vulgaris, vitexin-2-O-xyloside, betalains, antitumoral activity, CaCo-2 cancer cell line, nutraceutical products.

This item was downloaded from IRIS Università di Bologna (https://cris.unibo.it/)

When citing, please refer to the published version. 


\section{Introduction}

Swiss chard (Beta vulgaris var. cicla L.; BVc) and beetroot (Beta vulgaris var. rubra L., BVr) are vegetables of the Chenopodiaceae family, which have been part of the traditional western diet for ages. These vegetables have been used in folk medicine as a therapy for tumors of the digestive system, breast, prostate and uterus (Ninfali \& Angelino, 2013).

From a nutritional standpoint, BVc is one of the most powerful antioxidant vegetable (Ninfali \& Bacchiocca, 2003), due to the presence of a class of flavonoids derived from apigenin, namely vitexin, vitexin-2-O-glycoside, vitexin-2-O-rhamnoside and vitexin-2-O-xyloside (XVX). All these molecules, with the exception of XVX, are commercially available. XVX has been purified from hawthorn leaves (Ma, Liu, Xu, Yu, Zhang, \& Liu, 2010) or BVc seeds (Gennari et al., 2011) and its cytotoxicity in cancer cell lines has been previously demonstrated (Ma et al., 2010). In addition, a synergistic cytotoxic effect of XVX in combination with epigallocatechin-3-gallate and isothiocyanates in colon cancer cell lines has also been reported (Papi et al., 2013).

The red beetroot (BVr) extract possesses relevant antioxidant activity (Kugler et al., 2007) thanks to a class of molecules grouped under the name of betalains, derived from betalamic acid (Stintzing et al., 2004). Betalains are subdivided into red-violet betacyanins and yellow betaxanthins: with the former showing a higher antioxidant activity than the latter, as shown by both ABTS and FRAP methods (Castellar, Solano, \& Obon, 2012; Feugang, Konarski, Zou, Stintzing, \& Zou, 2006; Kugler et al., 2007). After studying betalains and other natural food colorant, Reddy, Alexander-Lindo, \& Nair (2005) showed that betacyanins inhibited lipid peroxidation and growth of several tumor cell lines. However, when combined with antocyanins, betacyanins were not able to inhibit the tumor cell growth, as well as the pro-inflammatory cyclooxygenase- 2 enzyme, as the two molecules proved to be antagonistic (Reddy et al., 2005). Two isoforms of cyclooxygenase (COX) have been identified and referred to as COX-1 and COX-2. While COX-1 is constitutively expressed in tissues, COX-2 is 
an inducible isoform and its expression is up-regulated by cytokines, mitogens, growth factors and carcinogens (Schneider \& Pozzi, 2011). COX-2 levels have been reported to increase dramatically in ulcerative colitis (Sheng, Shao, Morrow, Beauchamp, \& Dubois, 1998) and colorectal cancer (CRC) (Hardy, Meltzer, \& Jankowski, 2000). Genetic (Strillacci et al., 2010) and pharmacological (Schneider et al., 2011) inhibition of COX-2 has resulted in decreased incidence of primary and metastatic tumor growth, making COX-2 and its products ideal targets for anti-neoplastic therapy. Many natural compounds are able to inhibit COX-2 activity: resveratrol, epigallocatechin-3-gallate and tyrosol from olive oil extract (Schneider et al., 2011). Although most of the pro-tumorigenic activity of COX-2 is attributed to the generation of prostaglandin E2 (PGE2), other COX-2 derived products may also affect tumor development: prostaglandin F2 $\alpha$ (PGF2 $\alpha$ ) and thromboxane (TxA2). High levels of PGE2 can increase Interleukin-8 (IL-8) mRNA and protein production in colonic epithelial cells, contributing to the inflammation process in the gastrointestinal tract (Yu \& Chadee, 1998). IL-8 is the principal inflammatory cytokine involved in the inflammation process, which can lead to the development of colon cancer (Lee et al., 2012). It is therefore important for human health to reduce inflammation by means of natural compounds contained in foods, such as betalains from red beetroot.

The betalain content of five red beetroot varieties was determined by Gasztonyi, Daood, Hájos, \& Biacs (2001), who concluded that the red beet variety Detroit is one of the richest in pigment. Several medium pressure liquid cromatography (MPLC) methods have been used for purification of betalains from red beetroot (Račkauskienė, Pukalskas, Venskutonis, Fiore, Troise, \& Fogliano, 2015). Betalains can be separated into betacyanins and betaxanthins in different stationary phases such as hydrophobic interactions and anion exchange resins (Stintzing, Conrad, Klaiber, Beifuss, \& Carle, 2004). Higher purification grade and complete separation of betalains have been obtained using preparative high performance liquid chromatography (HPLC) techniques, but with low yields This item was downloaded from IRIS Università di Bologna (https://cris.unibo.it/) When citing, please refer to the published version. 
(Kugler, Stintzing, \& Carle, 2004). The aim of this paper was to develop a simple scale up method for the purification of definite fractions of betacyanins and betaxanthins and to test their cytotoxic effect individually and in combination with XVX in CaCo-2 colon cancer cells, which are characterized by mutated TP53 gene and over expression of multi-drug resistance (MDR) proteins (Piccirillo, Filomeni, Brune, Rotilio, \& Ciriolo, 2009).

\section{Materials and methods}

\subsection{Chemicals}

Ethanol and ethyl-acetate (analytical grade) were purchased from VWR International (Radnor, USA). Fluorescein sodium salt, 6-hydroxy-2,5,7,8-tetramethyl-2-carboxylic acid (Trolox), DMEM culture medium, foetal bovine serum (FBS), antibiotics, trypsin, water (LC-MS grade), acetonitrile (LC-MS grade) and formic acid (LC-MS grade) from Sigma-Aldrich (St. Louis, USA). 2,2'-azobis (2amidinopropane) dihydrochloride (AAPH) was obtained from Polysciences, Inc. (Warrington, USA). Lipopolysaccharide (LPS) (Sigma-Aldrich, St. Louis, USA) was used at $1 \mu \mathrm{g} / \mathrm{ml}$ final concentration. This concentration did not affect cell viability (data not shown).

\subsection{Plant material}

Seeds of BVc were obtained from Suba Seeds Company S.r.l. (Longiano, Italy). Seeds were identified by a lot number and the company ensured the quality and the homogeneity of the product. Seeds were stored at room temperature in a dry dark environment. Red beetroots (cv. Detroit) were cultivated in Castel Cavallino, Urbino (Italy). The beetroots were harvested at a stage of commercial harvest maturity, washed and $100 \mathrm{~g}$ of roots were used for the extraction of the betalains.

\subsection{Preparation of XVX}

The compound was isolated from seeds of BVc (cv. Bietola verde da taglio). The extract from seeds was prepared by solid-liquid extraction with $70 \%$ ethanol in a Timatic extractor (Tecnolab S.r.l.,

This item was downloaded from IRIS Università di Bologna (https://cris.unibo.it/)

When citing, please refer to the published version. 
Spello, Italy) and liquid-liquid extraction with ethyl-acetate, as previously reported (Gennari et al., 2011). Two chromatography columns were then applied: a Diaion HP-20 (Sigma-Aldrich, St. Louis, USA) and a Davisil C18 (ALLTECH, Milan, Italy), performed by means of a LC-Chromatograph AKTA Purifier 10 (GE Healthcare Bio-Sciences AB, Uppsala, Sweden) following the elution of XVX at $336 \mathrm{~nm}$. The elution phase of the Diaion HP 20 was $30 \%$ ethanol, isocratic; an elution gradient composed by formic acid $0.05 \%$ (buffer A) and ethanol 60\% (buffer B) was used for Davisil C18. Three phenol fractions were obtained: P1, P2 and P3. P1 did not contain XVX and was discarded, whereas $\mathrm{P} 2$ and $\mathrm{P} 3$, containing $95 \%$ and $70 \%$ of $\mathrm{XVX}$, respectively, were stored. For all the experiments performed on cells, we used the P2 fraction only.

\subsection{Purification of Betalains}

The beetroots were grated and extracted $(1: 10 \mathrm{w} / \mathrm{v})$ with $70 \%$ ethanol in $10 \mathrm{mM}$ Na-acetate buffer pH 5.0 for $2 \mathrm{~h}$ under stirring at $+6{ }^{\circ} \mathrm{C}$. The extract was filtered and concentrated by rotavap until reaching $10 \%$ of the initial volume, then subjected to liquid-liquid extraction with ethyl acetate. The remaining aqueous extract containing the betalains was lyophilized and stored at $-80^{\circ} \mathrm{C}$. Betalain subfamilies were isolated by means of a DEAE Sepharose fast flow (GE Healthcare Bio-Sciences AB, Uppsala, Sweden) column chromatography, performed by means of the LC-Chromatograph AKTA Purifier 10, (GE Healtheare Bio-Seiences AB, Uppsala, Sweden) as follows. The lyophilized extract $(5 \mathrm{~g})$ was suspended in $10 \mathrm{mM}$ Na-phosphate buffer pH 7.5 and loaded onto the column (5.0 $\times 30 \mathrm{~cm}$ ). The separation of the betaxanthins from the betacyanins was achieved with a $\mathrm{NaCl}$ gradient from 0 to $0.5 \mathrm{M}$ in $10 \mathrm{mM}$ Na-phosphate buffer $\mathrm{pH}$ 7.5. Betalains were assayed by reading the absorbance at $536 \mathrm{~nm}$ and $477 \mathrm{~nm}$ and using an extinction coefficient at $1 \%$ i.e. $\mathrm{E}^{1 \mathrm{~cm}_{1 \%}=1120 \text { at } 536}$

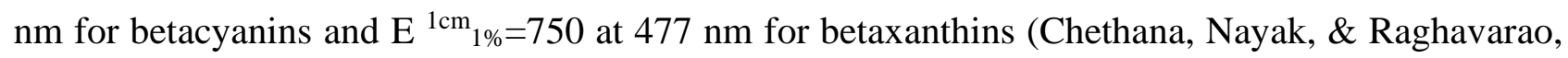
2007; Nilsson, 1970). Figure 1A shows the chromatographic profile of the DEAE Sepharose fast flow column with the gradient applied for the elution of betalains. Three fractions were obtained and

This item was downloaded from IRIS Università di Bologna (https://cris.unibo.it/)

When citing, please refer to the published version. 
labeled as R1, R2 and R3. After lyophilization, R1 was a yellow powder with maximal absorbance at $477 \mathrm{~nm}$. R2 was a red powder with maximal absorbance at $536 \mathrm{~nm}$, corresponding to betacyanins. R3 was found as a yellow pigment with spectra $\lambda$ max at 330, 399 and $477 \mathrm{~nm}$ which indicated the presence of a betaxanthin together with flavonoids (Vulic et al., 2013). Since the components of R3 were unknown it was not used for cells treatments, waiting for its complete identification. Therefore, we proceeded with HPLC - diode array detector (DAD) analysis of R1 and R2, in order to characterize them for the cells treatments experiments.

\subsection{Analysis by HPLC-DAD}

Samples of the lyophilized betalains peaks R1 and R2 were dissolved into the mobile phase and analyzed by HPLC-DAD as reported (Cejudo-Bastante, Chaalal, Louaileche, Parrado, \& Heredia, 2014). The HPLC was equipped with a Spherisorb ODS2 column (Waters Corporation, Milford, USA), with the dimensions of $4.6 \times 250 \mathrm{~mm}$; the particle size was $5 \mu \mathrm{m}$. Standard and sample volumes were $20 \mu$ l. Separation of betalains was performed using $1 \%$ formic acid in water (solvent A) and methanol (solvent B). A linear gradient was applied starting from 0 to $10 \% \mathrm{~B}$ in 20 min, then from 10 to $30 \% \mathrm{~B}$ in $10 \mathrm{~min}$, then from 30 to $100 \% \mathrm{~B}$ in $5 \mathrm{~min}$. To re-establish the initial conditions, a linear gradient from 100\% B to $100 \%$ A was used during 5 min. Detection was performed at 536 $\mathrm{nm}$ and $477 \mathrm{~nm}$ for red-violet and yellow pigments, respectively. Figure 1B shows the HPLC chromatogram of the beetroot crude extract, that evidenced 4 distinct peaks. The upper inset of Figure 1B shows the HPLC chromatogram of R1 presenting a main peak. R2 was found to be composed mainly by three betacyanins with maximal absorbance at $536 \mathrm{~nm}$ (Figure 1B, lower inset). The main peaks in R1 and R2 were identified by HPLC-ESI-MS.

The HPLC analysis of the XVX was performed on the same equipment with a gradient consisting into $0.01 \%$ acetic acid in water (solvent A) and methanol containing $0.01 \%$ acetic acid (solvent B).

This item was downloaded from IRIS Università di Bologna (https://cris.unibo.it/)

When citing, please refer to the published version. 
The gradient was the following: from 0 to $60 \%$ solvent $\mathrm{B}$ in $45 \mathrm{~min}$ at $1 \mathrm{ml} / \mathrm{min}$, then to $100 \% \mathrm{~B}$ in 5 min. XVX was identified using a purified standard available in our lab (Gennari et al., 2011).

\subsection{HPLC-ESI-MS}

A Series 200 Micro Pump HPLC system (Perkin Elmer, Norwalk, USA) was equipped with an API 150 EX (Applied Biosystems, Inc., Foster City, USA) mass spectrometer with an electrospray ionisation (ESI) source. The column and gradient were the same as those used for the analytical HPLC. The injection volume was $20 \mu \mathrm{l}$ and the flow rate was $1 \mathrm{ml} / \mathrm{min}$, split to $0.2 \mathrm{ml} / \mathrm{min}$ to the ESI source. Compounds were identified analysing the $\mathrm{m} / \mathrm{z}$ of molecular ions $\left(\mathrm{ESI}^{+}\right)$and by comparing them with those found in the literature databases and UV/Vis spectra. The peak of R1 (Figure 1B upper inset) was identified by mass spectrometry (MS) analysis as vulgaxanthin I (Gasztonyi et al., 2001). The three peaks of R2 were composed of three betacyanins identified in the decreasing order as betanin, isobetanin, betanidin (Figure 1B lower inset).

\subsection{Determination of antioxidant activity}

Antioxidant capacity was measured by the Oxygen Radical Antioxidant Capacity (ORAC) method as previously reported (Ninfali, Chiarabini, \& Angelino, 2014). The ORAC values were expressed as micromoles Trolox equivalents (TE)/g of dry beetroot fraction.

\subsection{Cell culture}

CaCo-2 colon cancer cell line was purchased from the American Type Culture Collection (ATCC, Rockville, USA) and maintained in DMEM supplemented with 10\% fetal bovine serum (FBS), 2 mM glutamine, $100 \mathrm{U} / \mathrm{ml}$ penicillin, $100 \mu \mathrm{g} / \mathrm{ml}$ streptomycin and $100 \mu \mathrm{M}$ MEM non-essential amino acid solution and grown at $37^{\circ} \mathrm{C}$ in a humidified atmosphere with $5 \% \mathrm{CO}_{2}$. Media and supplements were purchased from Sigma-Aldrich (St. Louis, USA).

2.9 Sulforhodamine B (SRB) assay

This item was downloaded from IRIS Università di Bologna (https://cris.unibo.it/)

When citing, please refer to the published version. 
The SRB assay is based on the ability of SRB dye to bind basic protein amino acid residues. The amount of dye, incorporated by the cells, indicates the cell number. Cells $\left(10^{4} /\right.$ well) were plated in 96-well plates and treated with XVX, R1 and R2 for 24, 48 and 72 hours. At the end of treatment, cell culture medium was removed, and the cells were fixed using $100 \mu \mathrm{l} /$ well of $50 \%$ aqueous trichloroacetic acid for $1 \mathrm{~h}$ at $4{ }^{\circ} \mathrm{C}$, rinsed with water several times and incubated for $30 \mathrm{~min}$ with 100 $\mu \mathrm{l} /$ well SRB solution (0.4\%) (Sigma-Aldrich, St. Louis, USA). After rinsing with $1 \%$ acetic acid and solubilizing in $10 \mathrm{mM}$ Tris for $20 \mathrm{~min}$, the absorbance of each well was measured in a microplate reader (BioRad Laboratories, Hercules, USA) at $570 \mathrm{~nm}$. The results were expressed as a percentage of cell mortality referred to control.

\subsection{Synergy evaluation}

Compounds were tested individually and mixed in pairs or in triple combination in the cell culture medium and the cytotoxicity was evaluated by the SRB assay. The measured cell viability (V\%) was converted into \% of growth inhibitory effect (GIE) by the calculation: \% GIE $=(100-\mathrm{V} \%)$ and this value was taken as an indication of the cytotoxic effect. The experimentally "Measured Cytotoxicity" in each mixture was divided by the "Expected Cytotoxicity", which is the mathematical sum of the cytotoxicity derived from the individual phytochemicals. If measured values were significantly higher than expected values, i.e. Measured/Expected Ratio $>1.0(\mathrm{p}<0.05)$, a synergistic effect was considered to have occurred. A Measured/Expected Ratio $<1.0(\mathrm{p}<0.05)$ indicated an antagonistic effect; a Measured/Expected Ratio = $1.0(\mathrm{p}<0.05)$ indicated an additive interaction (Papi et al., 2013).

\subsection{Western blot}

To determine Bcl2-like protein 4 (Bax), protein B-cell leukemia/lymphoma 2 (Bcl2), Caspase 3 and poly(ADP-ribose) polymerase-1 (PARP-1) protein levels, the CaCo-2 cancer cells were plated and treated with XVX, R1 and R2 individually and in the mixture. After treatment, cells were detached, collected by centrifugation at $300 \mathrm{~g}$ for $5 \mathrm{~min}$, and the pellets were suspended in lysis buffer (20 $\mathrm{mM}$

This item was downloaded from IRIS Università di Bologna (https://cris.unibo.it/)

When citing, please refer to the published version. 
Tris- $\mathrm{HCl}, \mathrm{pH}$ 7.5, $0.5 \mathrm{mM}$ EDTA, $0.5 \%$ Triton $\left.\mathrm{X}-100,5 \mu \mathrm{M} \mathrm{Na} \mathrm{VO}_{4}\right)$ and sonicated on ice, in the presence of protease inhibitors. Proteins $(50 \mu \mathrm{g})$ from cell lysate were size fractioned in $12 \%$ SDSpolyacrylamide gel, and transferred to Hybond TM-C Extra membranes (GE Healthcare, Little Chalfont, UK) by standard protocols. After the blocking phase, the following antibodies were used according to supplier recommended concentrations: anti-Caspase 3 (Sigma-Aldrich, St. Louis, USA), anti-PARP-1 (Santa Cruz Biotechnology, Inc., Dallas, USA), anti-Bax (Applied Biosystems Inc., Foster City, USA), anti-Bcl2 (Sigma-Aldrich, St. Louis, USA). The primary antibodies were diluted 1:500 in TBS-5\% milk and the respective peroxidase-conjugated secondary antibody was diluted 1:1000. The proteins were detected by luminol (GE Healthcare, Little Chalfont, UK). Bands were quantified by using densitometric images analysis software (Image Master VDS, Pharmacia LKB Biotechnology AB, Uppsala, Sweden). Protein loading was controlled by actin (1:1000) (SigmaAldrich, St. Louis, USA) detection after stripping of membranes with stripping solution (Thermo Fisher Scientific, Waltham, USA). Values were normalised against the actin control and statistically evaluated.

\subsection{Reactive Oxygen Species (ROS) assay}

Generation of ROS in $\mathrm{CaCo}-2$ cells was monitored by the conversion of 2',7'dichlorodihydrofluorescein diacetate (DCFH-DA) to highly fluorescent dichlorofluorescein (DCF). DCFH-DA is transformed by cellular esterase into the reduced not fluorescent form DCFH, which, in the presence of ROS, is oxidized to highly fluorescent DCF. Cells were grown on coverslips ( $2 \times 10^{4} /$ well) in 24 well plates and treated for $24 \mathrm{~h}$ with $\mathrm{R} 1$ and $\mathrm{R} 2$ individually and in combination and then incubated with $1 \mathrm{mM} \mathrm{H} \mathrm{H}_{2}$ for $1 \mathrm{~h}$ at room temperature. Control cells did not receive any treatment, whereas another sample was only treated with $1 \mathrm{mM} \mathrm{H}_{2} \mathrm{O}_{2}$ for $1 \mathrm{~h}$ as a positive control. After washing with PBS, all the samples were incubated in the dark for 20 min with $10 \mu \mathrm{M}$ DCF-DA (Sigma-Aldrich, St. Louis, USA) dissolved in PBS. After incubation, the cells were rinsed three times

This item was downloaded from IRIS Università di Bologna (https://cris.unibo.it/)

When citing, please refer to the published version. 
with PBS and mounted with a solution of Hoescht $(10 \mu \mathrm{g} / \mathrm{ml})$ and 1,4-diazabicyclo[2.2.2]octane (DABCO) (both from Sigma-Aldrich, St. Louis, USA). The samples were observed with an epifluorescence microscope (Nikon Instruments Europe BV, Amsterdam, Holland) equipped with filters for Hoescht and FITC. Cells showing a bright and intense fluorescence were counted as positive, whereas cells with no or low fluorescence were counted as negative. At least 3 fields for sample were analysed and 100-200 cells were counted. Results were expressed as \% DCF fluorescent positive cells vs control.

\subsection{RNA extraction and RTqPCR (Real Time quantitative PCR) for COX-2 and IL-8}

CaCo-2 cells were all incubated with LPS $(1 \mu \mathrm{g} / \mathrm{ml})$ for $25 \mathrm{~min}$ and then were treated for $24 \mathrm{~h}$ with XVX $(25 \mu \mathrm{g} / \mathrm{ml}),(X V X)$, or R1 $(0.35 \mu \mathrm{g} / \mathrm{ml})(\mathrm{R} 1)$, or R2 (0.25 $\mu \mathrm{g} / \mathrm{ml})(\mathrm{R} 2)$, or R1+R2 (R1+R2) or $\mathrm{XVX}+\mathrm{R} 1+\mathrm{R} 2(\mathrm{XVX}+\mathrm{R} 1+\mathrm{R} 2)$ and results were compared to those of the cells that have not been treated with phytochemicals (LPS only).

Total RNA was extracted from CaCo-2 cells using TRIzol (Thermo Fisher Scientific, Waltham, USA) reagent. RNA $(1.5 \mu \mathrm{g})$ of each sample was reverse transcribed using RevertAid First Strand cDNA Synthesis Kit (Thermo Fisher Scientific, Waltham, USA) following the manufacturer's protocol. RTqPCR analysis of cDNA was performed using a fluorescent nucleic acid dye (SsoFast ${ }^{\mathrm{TM}}$ EvaGreen Supermix, BioRad Laboratories, Hercules, USA) in a CFX96 system (BioRad Laboratories, Hercules, USA). We used the $2^{-\Delta \Delta C \mathrm{~T}}$ method for relative quantification of gene expression. $\beta$-Actin was used as the house keeping gene. The list of primers was the following: Actin: F:5'GGCATCGTGATGGACTCCG-3', R-5'-GCTGGAAGGTGGACAGCGA-3' (192 bp); IL-8: F-5'GCTTTCTGATGGAAGAGAGC-3', R-5'-GGCACAGTGGAACAAGGACT-3' (220 bp); COX-2: F:5'-CCTGTGCCTGATGATTGC-3',R:5'-CTGATGCGTGAAGTGCTG-3' (162 bp).

\subsection{Statistical analysis}

This item was downloaded from IRIS Università di Bologna (https://cris.unibo.it/)

When citing, please refer to the published version. 
Experiments were replicated three times with three samples analyzed per replicate. Results were expressed as mean \pm SD of nine obtained values. Statistical significance was assessed by one-way ANOVA, using PRISM 5.1 (GraphPad Software, La Jolla, USA). The results have been considered statistically significant when $p<0.05$.

\section{Results and discussion}

\subsection{Composition of $R 1$ and $R 2$}

The composition of R1 and R2 is summarized in Table $\mathbf{1}$ and it has been determined through absorbance values, HPLC retention times and MS analysis. This table also shows the antioxidant activity, measured by means of the ORAC method, of the R1 and R2 fractions, together with the betalains yields obtained in the purification process.

The chromatographic profile of the DEAE FF column chromatography is shown in Figure 1A. The purification process was scaled up to $5 \mathrm{~g}$ of dry extract, dissolved into $40 \mathrm{ml}$ of equilibrating buffer, loaded onto the column. Considering the total areas of the three peaks, it was determined that the betaxanthins of $\mathrm{R} 1$ represent the $11 \%$ of the sum of the peaks area and that the betacyanins of R2 represent the $61 \%$. Since the R3 peak, accounting for $28 \%$ of the whole peaks area, was discarded for its content of flavonoids, we were able to obtain, for each $5 \mathrm{~g}$ of extract processed with the DEAE FF chromatography, $0.5 \pm 0.1 \mathrm{~g}$ of lyophilized R1 and $3.5 \pm 0.5 \mathrm{~g}$ of R2 were obtained.

The R2 fraction was that endowed of the highest antioxidant capacity, thus confirming data reported in literature regarding the higher antioxidant capacity of betacyanins, compared to betaxanthins (Kugler et al., 2007). As R1 was entirely composed by betaxanthins and R2 by betacyanins (Table 1), these two fractions were utilized for in vitro cytotoxicity studies in CaCo-2 cancer cell line.

3.2 Antiradical activity of R1 and R2 as detected by DCF-DA assay induced The oxidative stress was induced by $\mathrm{H}_{2} \mathrm{O}_{2}$, which elicits ROS production, that can be visualized by the DCF-DA This item was downloaded from IRIS Università di Bologna (https://cris.unibo.it/)

When citing, please refer to the published version. 
assay. CaCo-2 cells were treated with $\mathrm{R} 1$ or $\mathrm{R} 2$ or $\mathrm{R} 1+\mathrm{R} 2$ for $24 \mathrm{~h}$, then $1 \mathrm{mM} \mathrm{H}_{2} \mathrm{O}_{2}$ was administered for $1 \mathrm{~h}$ and the presence of ROS was evaluated by the DCF-DA assay (Figure 2). Cells producing ROS showed intense green fluorescence and could be evaluated as positive. In untreated control cells, rare positive cells were detected $(6 \pm 3 \%)$, whereas in CaCo-2 cells only treated with $\mathrm{H}_{2} \mathrm{O}_{2}$, the percentage of positive cells increased to $71 \pm 13 \%$ (Figure 2). The positive cells percentage decreased to $6.2 \pm 3.1 \%$ and $3.5 \pm 1.4 \%$ when the $\mathrm{CaCo}-2$ cells were pretreated with $\mathrm{R} 1$ or $\mathrm{R} 2$, respectively. Moreover, the fluorescent cells decreased to $2.4 \pm 0.6 \%$ when pre-treated with $\mathrm{R} 1+\mathrm{R} 2$ (Figure 2). These findings showed a powerful antioxidant activity for R1 and R2, when used alone and in combination. The fact that $\mathrm{R} 1$ and $\mathrm{R} 2$ were able to reduce the oxidative damage, induced by $\mathrm{H}_{2} \mathrm{O}_{2}$ directly into the cells, shows that the betaxanthins and betacyanins contained in the $\mathrm{R} 1$ and $\mathrm{R} 2$ fractions are able to cross the membranes and exert their antioxidant activity inside the cells.

\subsection{Cytotoxicity of XVX, R1 and R2 in Caco-2 cells}

We first investigated The cytotoxicity of the individual phytochemicals was investigated. CaCo-2 cells were incubated with various concentrations of XVX for 24, 48 and $72 \mathrm{~h}$ and SRB assay was performed. The dose-response cytotoxic effect of XVX in the $12.5-50 \mu \mathrm{g} / \mathrm{ml}$ range is shown in Figure 3A. XVX exhibited the greatest effect on CaCo- 2 cells viability when used at $50 \mu \mathrm{g} / \mathrm{ml}$. The IC 50 value was found at $25 \mu \mathrm{g} / \mathrm{ml}$ after 24 and 48 hours of incubation. At $25 \mu \mathrm{g} / \mathrm{ml} \mathrm{XVX} \mathrm{concentration,}$ the effect on cells viability was more relevant at 24 and $48 \mathrm{~h}$ than at $72 \mathrm{~h}$, when a significant decrease in cell mortality was observed $(\mathrm{p}=0.004)$. The cell death decrease at $72 \mathrm{~h}$ could mean that the CaCo2 cells have the ability to metabolize or extrude part of the XVX within $72 \mathrm{~h}$. On the contrary, at 50 $\mu \mathrm{g} / \mathrm{ml} \mathrm{XVX}$ concentration, the cytotoxic effect increased over time with the maximum effect at $72 \mathrm{~h}$ $(p=0.002)$. Hence, at this concentration, XVX showed sustained strong cytotoxicity over the testing period and the cells showed a less efficiency in metabolizing and extruding higher concentrations of the drug. were unable to metabolize or extrude the drugA hormetic effect was observed when CaCo- 
2 cells were incubated with increasing concentrations of R1 and R2 fractions In fact, cytotoxicity was more evident at lower concentrations, than at higher concentrations (Figure 3B, Inset). Regarding the specific cytotoxic concentrations, the highest effect was observed at $0.35 \mu \mathrm{g} / \mathrm{ml} \mathrm{R} 1$ and $0.25 \mu \mathrm{g} / \mathrm{ml} \mathrm{R} 2$. The cytotoxic effect of individual R1 and R2 was analysed in time-course experiments. The effect of 0.35 and $0.25 \mu \mathrm{g} / \mathrm{ml} \mathrm{R} 1$ and $\mathrm{R} 2$ in CaCo-2 cells incubated for 24,48 and $72 \mathrm{~h}$ is shown in Figure 3B. The cytotoxicity of both $\mathrm{R} 1(p=0.036)$ and $\mathrm{R} 2(\mathrm{p}=0.026)$ significantly decreased after $72 \mathrm{~h}$ of treatment, thus indicating that CaCo-2 cells are able to metabolize and/or extrude R1 and R2.

In order to evaluate a possible synergistic effect of XVX in combination with $\mathrm{R} 1$ or $\mathrm{R} 2$, wsed the $25 \mu \mathrm{g} / \mathrm{ml} \mathrm{XVX}$ concentration, corresponding to the $\mathrm{IC}_{50}$ value, was used in combination with 0.35 or $0.25 \mu \mathrm{g} / \mathrm{ml} \mathrm{R} 1$ or R2, respectively. XVX combined with R1 $(p=0.003)$ or R2 $(p=0.007)$, exhibited, in both cases, a high and significant cytotoxic effect even after $72 \mathrm{~h}$ of treatment (Figure $3 \mathrm{C}$ ). In fact, the XVX $+\mathrm{R} 1$ combination induced $67.7 \pm 7.9 \%$ cells mortality, while the XVX $+\mathrm{R} 2$ combination induced $68.9 \pm 3.8 \%$. These results showed that both R1 and R2 exhibited a synergistic cytotoxic effect when used in combination with XVX. The synergy was evaluated by calculating the ratio of the measured/expected cytotoxicity, which was $1.53 \pm 0.15$ for $\mathrm{XVX}+\mathrm{R} 1$ and $1.54 \pm 0.16$ for XVX + R2 (Table 1, Supplementary). The ability of betalains to enhance XVX cytotoxicity may stem from their capacity to hamper XVX catabolism or inhibit its expulsion from the cells, probably by modulating the Multidrug resistance (MDR) system (Eid, El-Readi, Eldin, Fatani, \& Wink, 2013). We also tested The cytotoxic effect in CaCo- 2 cells of the triple combination XVX $+\mathrm{R} 1+\mathrm{R} 2$ at the same concentrations used for the above mentioned combinations was also tested. The triple combination was the most cytotoxic combination for CaCo-2 cells, especially when used in the $24 \mathrm{~h}$ treatment (Figure 3C), when compared to XVX $+\mathrm{R} 1$ treatment $(p<0.001)$ and $\mathrm{XVX}+\mathrm{R} 2$ treatment $(p<0.001)$. These results highlight the ability of the triple combination to maintain cytotoxicity This item was downloaded from IRIS Università di Bologna (https://cris.unibo.it/) When citing, please refer to the published version. 
through $72 \mathrm{~h}$, when the cells mortality was $85.6 \pm 5.1 \%$ and the measured/expected ratio was $1.39 \pm$

\subsection{4 (Table 1, Supplementary).}

These results prompted us to analyse the effects of single phytochemicals and the triple combination on the molecular targets involved in the induction of apoptosis in $\mathrm{CaCo}-2$ cells, as previously demonstrated for XVX (Papi et al., 2013).

\subsection{Apoptosis induction in Caco-2 cells}

$\mathrm{XVX}, \mathrm{R} 1$ and $\mathrm{R} 2$ used alone or in the triple combination were incubated for $24 \mathrm{~h}$ with the CaCo-2 cells and Bcl-2, Bax, Caspase 3 and poly(ADP-ribose) polymerase-1 (PARP-1) expression levels were evaluated. The effects of these phytochemicals on the expression of the above mentioned molecular targets, involved in the apoptotic process, are shown in Figure 4. Bcl-2 protein expression levels significantly decreased in the presence of $\mathrm{R} 1$ and $\mathrm{XVX}+\mathrm{R} 2+\mathrm{R} 1$, but not in the presence of R2 or XVX alone. Conversely, the Bax protein expression levels increased with individual concentrations of $\mathrm{R} 2$, as well as with the combination of $\mathrm{XVX}+\mathrm{R} 2+\mathrm{R} 1$, but not with the treatment with R1 or XVX alone. Cleaved PARP-1 levels significantly increased compared to the untreated cells, both with the individual concentrations of XVX, R2 and R1 as well as with the combination of $\mathrm{XVX}+\mathrm{R} 2+\mathrm{R} 1$. The levels of cleaved Caspase 3 increased significantly with individual treatments of XVX, R2 and R1 as well as with the triple combination (Figure 4).

Overall, a down regulation of $\mathrm{Bcl}-2$ was observed, together with an over expression of the proapoptotic Bax protein, with some individual compounds, but always with the triple combination. The $\mathrm{Bcl} 2 / \mathrm{Bax}$ ratio decrease is considered as an indicator of the activation of intrinsic (mitochondrial) pathway of apoptosis (Khan, Adhami, \& Mukhtar, 2008). The downstream apoptotic signaling molecules, represented by the cleaved Caspase 3 as well as the cleaved PARP-1, were consequently increased. Caspase 3 plays a central role in the execution phase of cell apoptosis as it is responsible of the proteolytic cleavage of PARP-1, a nuclear enzyme involved in DNA repair and stability, which

This item was downloaded from IRIS Università di Bologna (https://cris.unibo.it/)

When citing, please refer to the published version. 
is cut and then inactivated by Caspase 3. On the whole, our results show the activation of an intrinsic apoptotic pathway in $\mathrm{CaCo}-2$ cells, which was triggered to different extents by the individual compounds XVX, R1 and R2, but mainly by their combination. This means that there is a potential chemopreventive effect exerted by the three nutrients. Moreover, since these molecules were shown to be largely bioavailable (Tesoriere et al., 2013), a systemic cytoprotective effect in the intestine, liver and peripheral tissues is also conceivable.

\subsection{Transcriptional inhibition of COX-2 and IL-8}

We performed RTqPCR experiments were performed to evaluate the mRNA expression levels of IL8 and COX-2, the pro-inflammatory markers which support the over-proliferation of colon cancer cells (Sheng et al., 1998; Suh, Afaq, Johnson, \& Mukhtar, 2009). Detectable COX-2 and IL-8 mRNA levels were observed only after treatment with LPS, a known compound able to induce inflammation.

XVX alone induced a mild decrease in COX-2 mRNA expression levels; R1 also prompted a slight decrease in mRNA expression, whereas R2 markedly reduced mRNA expression levels. R1 + R2 as well as the triple combination $\mathrm{XVX}+\mathrm{R} 1+\mathrm{R} 2$ were both able to significantly reduce the mRNA expression levels of COX-2 (Figure 5A). Therefore, the R1 + R2 combination and also the triple combination $\mathrm{XVX}+\mathrm{R} 1+\mathrm{R} 2$ inhibited the expression of COX-2 and its product PGE2, which in turn is no longer able to induce the over expression of Bcl-2, the anti-apoptotic protein (Suh et al., 2009). Th series of events strengthens the cytotoxic effect of our phytochemicals in CaCo-2 colon cancer cells.

Moreover, since IL-8 is the principal cytokine involved in the inflammation process that can lead to colon cancer development (Lee et al., 2012), we also assessed whether our phytochemicals were able to regulate IL-8 mRNA expression levels was assessed.

This item was downloaded from IRIS Università di Bologna (https://cris.unibo.it/)

When citing, please refer to the published version. 
expression levels after XVX treatment was observed; whereas $\mathrm{R} 1, \mathrm{R} 2, \mathrm{R} 1+\mathrm{R} 2$ and $\mathrm{XVX}+\mathrm{R} 1+\mathrm{R} 2$ treatments were all able to significantly reduce IL-8 mRNA expression (Figure 5B).

\section{Conclusions}

We improved The present study describes an improved ion exchange column chromatography protocol for purification of gram quantities of betaxanthins and betacyanins from red beetroot, that were used for cytotoxicity studies alone and in combination with XVX, the main cytotoxic flavonoid from BVc seeds. Our results showed that XVX, R1 and R2 individual treatments exerted a cytotoxic effect in CaCo-2 tumor cell lines at 24 and $48 \mathrm{~h}$. Cytotoxicity of R1 and R2 showed a hormetic pattern and the highest cytotoxicity was observed when the fractions were used in the range of $0.25-0.35 \mu \mathrm{g} / \mathrm{ml}$, which is a quite low concentration range. In contrast, $\mathrm{XVX}$ showed its $\mathrm{IC}_{50}$ cytotoxic activity at $25 \mu \mathrm{g} / \mathrm{ml}$. The combinations of XVX $+\mathrm{R} 1, \mathrm{XVX}+\mathrm{R} 2$ and $\mathrm{XVX}+\mathrm{R} 1+\mathrm{R} 2$ led to a significant synergistic cytotoxic effect in CaCo-2 cells, with the highest cytotoxicity observed at 72 h. In other words, the cytotoxic effect of the couples and the triple combinations increased and protracted over the time. In a previous study (Papi et al., 2013), we demonstrated it has been shown that XVX could be more effective in triggering cancer cell death when combined with other phytochemicals. In the present study, we show it has been shown that there is a synergism among $\mathrm{XVX}, \mathrm{R} 1$ and $\mathrm{R} 2$ that could improve their individual cytotoxic effects,

A possible explanation for the increased cytotoxicity of the $\mathrm{XVX}+\mathrm{R} 1+\mathrm{R} 2$ treatment in comparison with XVX alone lies in the ability of betalains to significantly reduce COX-2 and IL- 8 mRNA expression levels. This inhibition leads to a down regulation of the anti-apoptotic protein $\mathrm{Bcl}-2$. In fact, our results show that XVX alone is not able to reduce Bcl-2 levels, while the triple combination $\mathrm{XVX}+\mathrm{R} 1+\mathrm{R} 2$ can significantly decrease it.

This item was downloaded from IRIS Università di Bologna (https://cris.unibo.it/)

When citing, please refer to the published version. 
We do not know It is unclear at present if the cytotoxic effect is triggered either by the intact phytochemicals or by their metabolites and therefore studies are in progress in our laboratory to detect the presence of metabolic products in the cells and in the culture medium.

Our findings also highlight the powerful antioxidant capacity of the two betalain fractions, as already reported (Esatbeyoglu, Wagner, Schini-Kerth, \& Rimbach, 2015; Tesoriere et al., 2013).-Our data also suggest that R1 and R2 and their combination may work efficiently as anti-oxidant agents against ROS compounds, even inside the cells, taking advantage of their remarkable ability to cross the cell membrane.

Both ORAC and DCF-DA assays demonstrated the antioxidant activity of R1 and R2, when used individually and in combination. $\mathrm{H}_{2} \mathrm{O}_{2}$ treatment triggered a robust ROS production, which was abolished when the cells were pre-treated with R1 and R2 for $24 \mathrm{~h}$. In this case, the antioxidant mechanisms, activated by R1 and R2, were able to contrast ROS development. It has already been demonstrated that betalains work as strong anti-oxidant agents through a direct scavenger mechanism exerted by hydroxyl and imino groups and through the regulation of Nuclear factor (erythroid-derived 2)-like 2 (Nrf2) expression and the increase of phase II enzymes levels (Tesoriere et al., 2012; Esatbeyoglu, et al., 2015). As ROS development was abolished in CaCo-2 cells that had taken R1 and R2 24 hours before $\mathrm{H}_{2} \mathrm{O}_{2}$ treatment, it could be hypothesized that $\mathrm{Nrf} 2$ and Phase II enzymes might be involved in the antioxidant activity of betalains. These findings support the hypothesis that $\mathrm{R} 1$ and R2 present in BVr belong to the family of antioxidant compounds found in foods (like vitamin E, genistein, epigallo-catechin-3-gallate, curcumin, piperine and sulforaphane) that are thought to inhibit cancer development (Su, Z.Y. et al.; 2012).

The present results also suggest that phytochemicals extracted from BVr might have very useful applications in tumor chemoprevention in vitro and in vivo studies: specific nutraceutical preparations or food derived mixtures, enriched with $\mathrm{XVX}$ and betalains from red beetroot or possibly from the 
food colorant E162 (widely used for human food preparations), might be proposed as diet components, with the aim of reducing and limiting cancer onset and development.

\section{Acknowledgments}

We acknowledge the financial support of the University of Urbino "Carlo Bo". The authors wish to thank Mr. Marco Golinucci, of the SUBA SEEDS COMPANY, for providing Swiss chard seeds. We are also indebted to Dr. Mauro Formica, University of Urbino and Dr. Ilona Di Maio, University of Perugia for their help in the identification of the betalains by UV-Vis spectra and HPLC/MS analysis. Finally, we are grateful to Gianluca Scarpa for his preparation of the Figures and to Timothy Bloom, a mother-tongue English language instructor, University of Urbino, for his editorial assistance regarding the English language.
Abbreviations
Bax $=$ Bcl2-like protein 4
Bcl2 = B-cell leukemia/lymphoma 2
BLS $=$ Betalains
$\mathrm{BVc}=$ Beta vulgaris var. cicla $\mathrm{L}$.
$\mathrm{BVr}=$ Beta vulgaris var. rubra $\mathrm{L}$.
COX-2 = Cyclooxygenase- 2
$\mathrm{CRC}=$ Colorectal carcinoma
$\mathrm{DAD}=$ Diode array detector

DCFH-DA = 2', 7' -dichlorodihydrofluorescein diacetate

$\mathrm{ESI}=$ electrospray ionisation

$\mathrm{GAE}=$ Gallic Acid Equivalent

HPLC-MS = High Pressure Liquid Cromatography-Mass Spectrometry

IL8 = Interleukin 8

This item was downloaded from IRIS Università di Bologna (https://cris.unibo.it/)

When citing, please refer to the published version. 
LPS = Lipopolysaccharide

MDR = Multi Drug Resistance

Nrf2 = Nuclear factor (erythroid-derived 2)-like 2

ORAC $=$ Oxygen Radical Antioxidant Capacity

PARP1 = Poly ADP-Ribosyl Polymerase 1

PGE2 $=$ Prostaglandin E2

ROS $=$ Reactive Oxygen Species

$\mathrm{SRB}=$ Sulforhodamine $\mathrm{B}$

$\mathrm{XVX}=$ Vitexin-2-O-xyloside

\section{Conflicts of interest}

The authors declare no conflict of interest.

\section{References}

Castellar, M. R., Solano, F., \& Obon, J. M. (2012). Betacyanin and other antioxidants production during growth of Opuntia stricta (Haw.) fruits. Plant Foods for Human Nutrition, 67, 337 343.

Cejudo-Bastante, M. J., Chaalal, M., Louaileche, H., Parrado, J., \& Heredia, F. J. (2014). Betalain profile, phenolic content, and color characterization of different parts and varieties of Opuntia ficus-indica. J. Agric. Food Chem, 62, 8491-8499.

Chethana, S., Nayak, C. A., \& Raghavarao, K. S. M. S. (2007). Aqueous two phase extraction for purification and concentration of betalains. Journal of Food Engineering, 81, 679-687.

Eid, S. Y., El-Readi, M. Z., Eldin, E. E., Fatani, S. H., \& Wink, M. (2013). Influence of combinations of digitonin with selected phenolics, terpenoids, and alkaloids on the expression and activity of P-glycoprotein in leukaemia and colon cancer cells. Phytomedicine, 21, 47-61.

This item was downloaded from IRIS Università di Bologna (https://cris.unibo.it/)

When citing, please refer to the published version. 
Esatbeyoglu, T., Wagner, A. E., Schini-Kerth, V. B., \& Rimbach, G. (2015). Betanin--a food colorant with biological activity. Molecular Nutrition \& Food Research, 59, 36-47.

Feugang, J. M., Konarski, P., Zou, D., Stintzing, F. C., \& Zou, C. (2006). Nutritional and medicinal use of Cactus pear (Opuntia spp.) cladodes and fruits. Frontiers in Bioscience, 11, 2574-2589.

Gasztonyi, M. N., Daood, H., Hájos, M. T., \& Biacs, P. (2001). Comparison of red beet (Beta vulgaris var conditiva) varieties on the basis of their pigment components. Journal of the Science of Food and Agriculture, 81, 932-933.

Gennari, L., Felletti, M., Blasa, M., Angelino, D., Celeghini, C., Corallini, A., \& Ninfali, P. (2011). Total extract of Beta vulgaris var. cicla seeds versus its purified phenolic components: antioxidant activities and antiproliferative effects against colon cancer cells. Phytochemical Analysis, 22, 272-279.

Hardy, R. G., Meltzer, S. J., \& Jankowski, J. A. (2000). ABC of colorectal cancer. Molecular basis for risk factors. British Medical Journal, 321, 886-889.

Khan, N., Adhami, V. M., \& Mukhtar, H. (2008). Apoptosis by dietary agents for prevention and treatment of cancer. Biochemical Pharmacology, 76, 1333-1339.

Kugler, F., Graneis, S., Stintzing, F. C., \& Carle, R. (2007). Studies on betaxanthin profiles of vegetables and fruits from the Chenopodiaceae and Cactaceae. Z Naturforsch C, 62, 311-318.

Kugler, F., Stintzing, F. C., \& Carle, R. (2004). Identification of betalains from petioles of differently colored Swiss chard (Beta vulgaris L. ssp. cicla [L.] Alef. Cv. Bright Lights) by highperformance liquid chromatography-electrospray ionization mass spectrometry. Journal of Agricultural and Food Chemistry, 52, 2975-2981.

Lee, Y. S., Choi, I., Ning, Y., Kim, N. Y., Khatchadourian, V., Yang, D., Chung, H. K., Choi, D., LaBonte, M. J., Ladner, R. D., Nagulapalli Venkata, K. C., Rosenberg, D. O., Petasis, N. A., Lenz, H. J., \& Hong, Y. K. (2012). Interleukin-8 and its receptor CXCR2 in the tumour This item was downloaded from IRIS Università di Bologna (https://cris.unibo.it/) 
microenvironment promote colon cancer growth, progression and metastasis. British Journal of Cancer, 106, 1833-1841.

Ma, L. Y., Liu, R. H., Xu, X. D., Yu, M. Q., Zhang, Q., \& Liu, H. L. (2010). The pharmacokinetics of $C$-glycosyl flavones of Hawthorn leaf flavonoids in rat after single dose oral administration. Phytomedicine, 17, 640-645.

Nilsson, T. (1970). Studies into the pigments in beetroot (Beta vulgaris L. ssp. vulgaris var. rubra L.). Lantbrukshogskolans Annaler, 36, 179-219.

Ninfali, P. \& Angelino, D. (2013). Nutritional and functional potential of Beta vulgaris cicla and rubra. Fitoterapia, 89, 188-199.

Ninfali, P. \& Bacchiocca, M. (2003). Polyphenols and antioxidant capacity of vegetables under fresh and frozen conditions. Journal of Agricultural and Food Chemistry, 51, 2222-2226.

Ninfali, P., Chiarabini, A., \& Angelino, D. (2014). The ORAC/kcal ratio qualifies nutritional and functional properties of fruit juices, nectars, and fruit drinks. International Journal of Food Sciences and Nutrition, 65, 708-712.

Ninfali, P., Mea, G., Giorgini, S., Rocehi, M., \& Bacchiocea, M. (2005). Antioxidant capacity of vegetables, spices and dressings relevant to nutrition. British Journal of Nutrition, 93, 257 266.

Papi, A., Farabegoli, F., Iori, R., Orlandi, M., De Nicola, G. R., Bagatta, M., Angelino, D., Gennari, L., \& Ninfali, P. (2013). Vitexin-2-O-xyloside, raphasatin and (-)-epigallocatechin-3-gallate synergistically affect cell growth and apoptosis of colon cancer cells. Food Chemistry, 138, 15211530.

Piccirillo, S., Filomeni, G., Brune, B., Rotilio, G., \& Ciriolo, M. R. (2009). Redox mechanisms involved in the selective activation of Nrf2-mediated resistance versus $\mathrm{p} 53$-dependent apoptosis in adenocarcinoma cells. The Journal of Biological Chemistry, 284, 27721-27733.

This item was downloaded from IRIS Università di Bologna (https://cris.unibo.it/)

When citing, please refer to the published version. 
Račkauskienė, I., Pukalskas, A., Venskutonis, P. R., Fiore, A., Troise, A. D., \& Fogliano, V. (2015). Effects of beetroot (Beta vulgaris) preparations on the Maillard reaction products in milk and meat-protein model systems. Food Research International, 70, 31-39.

Reddy, M. K., Alexander-Lindo, R. L., \& Nair, M. G. (2005). Relative inhibition of lipid peroxidation, cyclooxygenase enzymes, and human tumor cell proliferation by natural food colors. Journal of Agricultural and Food Chemistry, 53, 9268-9273.

Schneider, C. \& Pozzi, A. (2011). Cyclooxygenases and lipoxygenases in cancer. Cancer Metastasis Reviews, 30, 277-294.

Sheng, H., Shao, J., Morrow, J. D., Beauchamp, R. D., \& Dubois, R. N. (1998). Modulation of apoptosis and Bcl-2 expression by prostaglandin E2 in human colon cancer cells. Cancer Research, 58, 362-366.

Singleton, V. L., Orthofer, R., \& Lamuela-Raventos, R. M. (1999). Analysis of total phenols and other oxidation substrates and antioxidants by means of Folin-Ciocalteau reagent. Methods in Enzymology, 299, 152178.

Stintzing, F. C., Conrad, J., Klaiber, I., Beifuss, U., \& Carle, R. (2004). Structural investigations on betacyanin pigments by LC NMR and 2D NMR spectroscopy. Phytochemistry, 65, 415-422.

Stintzing, F. C., Kammerer, D., Schieber, A., Adama, H., Nacoulma, O. G., \& Carle, R. (2004). Betacyanins and phenolic compounds from Amaranthus spinosus L. and Boerhavia erecta L. Z Naturforsch C, 59, 1-8.

Strillacci, A., Griffoni, C., Lazzarini, G., Valerii, M. C., Di, M. S., Rizzello, F., Campieri, M., Moyer, M. P., Tomasi, V., \& Spisni, E. (2010). Selective cyclooxygenase-2 silencing mediated by engineered E. coli and RNA interference induces anti-tumour effects in human colon cancer cells. British Journal of Cancer, 103, 975-986.

This item was downloaded from IRIS Università di Bologna (https://cris.unibo.it/)

When citing, please refer to the published version. 
Su, Z.Y., Shu, L., Khor, T.O., Lee, J.H., Fuentes, F., \& Kong, A.N. (2013). A perspective on dietary phytochemicals and cancer chemoprevention: oxidative stress, nrf2, and epigenomics. Topics in Current Chemistry, 329, 133-162.

Suh, Y., Afaq, F., Johnson, J. J., \& Mukhtar, H. (2009). A plant flavonoid fisetin induces apoptosis in colon cancer cells by inhibition of COX2 and Wnt/EGFR/NF-kappaB-signaling pathways. Carcinogenesis, 30, 300-307.

Tesoriere, L., Gentile, C., Angileri, F., Attanzio, A., Tutone, M., Allegra, M., \& Livrea, M. A. (2013). Trans-epithelial transport of the betalain pigments indicaxanthin and betanin across Caco-2 cell monolayers and influence of food matrix. European Journal of Nutrition, 52, 1077-1087.

Vulic, J.J., Cebovic, T.N., Canadanovic, V.M., Cetkovic, G.S., Djilas, S.M., Canadanovic-Brunet, J.M., Velicanski, A.S., Cvetkovic, D.D., \& Tumbas, V.T. (2013). Antiradical, antimicrobial and cytotoxic activities of commercial beetroot pomace. Journal of Functional Foods, 4, 713721.

Yu, Y. \& Chadee, K. (1998). Prostaglandin E2 stimulates IL-8 gene expression in human colonic epithelial cells by a posttranscriptional mechanism. The Journal of Immunology, 161, 37463752.

This item was downloaded from IRIS Università di Bologna (https://cris.unibo.it/) 


\section{Figures captions}

Figure 1. Chromatographic profile obtained from the DEAE fast flow column loaded with red beetroot extract and HPLC chromatogram of the whole beetroot extract and of the separated fractions. A) R1, R2, R3 indicate the betalains peaks, obtained by reading absorbance of the fractions at $477 \mathrm{~nm}(\mathrm{R} 1$ and R3) and $536 \mathrm{~nm}(\mathrm{R} 2) . \mathrm{R} 1$ was eluted with a $0-0.08 \mathrm{M} \mathrm{NaCl}$ gradient in $10 \mathrm{mM}$ Na-phosphate buffer $\mathrm{pH} 7.5$; $\mathrm{R} 2$ was eluted with $0.08 \mathrm{M} \mathrm{NaCl}$ isocratic in the same buffer; R3 was eluted with a $0.08-0.5 \mathrm{M} \mathrm{NaCl}$ gradient in the same buffer. B) HPLC chromatogram of beetroot whole extract: peak 1 indicates vulgaxanthin I, peak 2 betanin, peak 3 isobetanin, peak 4 betanidin. ${ }^{\lambda}$ It indicates the change of reading Absorbance from 477 to $536 \mathrm{~nm}$ at $25 \mathrm{~min}$.

Figure 2. DCF-DA assay in CaCo-2 cells treated with phytochemicals before $\mathrm{H}_{2} \mathrm{O}_{2}$ treatment. CTRL, untreated cells; $\mathbf{H}_{2} \mathrm{O}_{2}$, cell treated with $1 \mathrm{mM} \mathrm{H}_{2} \mathrm{O}_{2}$ for $1 \mathrm{~h} ; \mathbf{R} 1$, cells treated with $0.35 \mu \mathrm{g} / \mathrm{ml}$ $\mathrm{R} 1$ for $24 \mathrm{~h}$ and then with $1 \mathrm{mM} \mathrm{H}_{2} \mathrm{O}_{2}$ for $1 \mathrm{~h}$; R2, cells treated with $0.25 \mu \mathrm{g} / \mathrm{ml} \mathrm{R} 2$ for $24 \mathrm{~h}$ and then with $1 \mathrm{mM} \mathrm{H}_{2} \mathrm{O}_{2}$ for $1 \mathrm{~h} ; \mathbf{R} 1+\mathbf{R 2}$, cells treated with $0.35 \mu \mathrm{g} / \mathrm{ml} \mathrm{R} 1+0.25 \mu \mathrm{g} / \mathrm{ml} \mathrm{R} 2$ for $24 \mathrm{~h}$ and then with $1 \mathrm{mM} \mathrm{H} \mathrm{H}_{2}$ for $1 \mathrm{~h}$. Data are expressed as average percentage of positive cells. At least three fields were evaluated and 100-200 cells were counted in each experiment. ${ }^{* *} p<0.01$.

Figure 3. Cytotoxic effects of XVX and $R 1$ and $R 2$ on CaCo-2 cells after 24, 48 and 72h treatments. The \% of cells mortality induced by XVX alone (A), R1 or R2 alone (B) and the combinations of XVX + R1, XVX + R2 and XVX + R1 + R2 (C), compared to control untreated cells (that had a mean of 5\% cells mortality), is shown. Figure 3B inset shows the hormetic effect of the cytotoxicity induced by R1 and R2 at 24h, which exhibited different cytotoxicity levels when used at low or high concentrations. ${ }^{*} p<0.05 ; * * p<0.01$; ***p $<0.001$; n.s., not statistically significant.

Figure 4. Detection of apoptosis in XVX, $R 1$ and $R 2$ treated CaCo-2 cell line by Western blot analysis. Cells were not treated (CTR); or treated with XVX $(25 \mu \mathrm{g} / \mathrm{ml}), \mathrm{R} 2(0.25 \mu \mathrm{g} / \mathrm{ml}), \mathrm{R} 1(0.35$ $\mu \mathrm{g} / \mathrm{ml}$ ), XVX + R2 + R1 at the same concentrations for $24 \mathrm{~h}$. Bcl2, Bax, cleaved PARP1 (PARP) and cleaved caspase 3 levels were assessed in cell lysate of CaCo-2 colon cancer cell line. The molecular

This item was downloaded from IRIS Università di Bologna (https://cris.unibo.it/)

When citing, please refer to the published version. 
weight (MW), expressed in $\mathrm{kDa}$, of each apoptosis molecular target is shown on the right side of the figure. Densitometric data were normalised to the levels of actin and were expressed as percentage of protein expression (mean \pm SD) in treated samples with respect to the control. Three replicate experiments with three samples per replicate were performed and the results were analysed. $* p<0.05$; n.s., not statistically 